\title{
APPLICABILITY OF THE AFRCWHEAT2 WHEAT GROWTH SIMULATION MODEL IN HUNGARY
}

\author{
N.HARNOS \\ Agricultural Research Institute of the Hungarian Academy of Sciences \\ P.O.Box 19. H-2462, Martonvásár, Hungary \\ (phone: +36-22-569-508) \\ e-mail:noemi@mail.mgki.hu
}

(Received $10^{\text {th }}$ Sep 2005 , accepted $10^{\text {th }}$ Oct 2006)

\begin{abstract}
The aim of the present work was to determine the applicability of the AFRCWHEAT2 wheat growth model under Hungarian conditions. The Farquhar model, which, when properly calibrated, gives a satisfactory description of the net photosynthesis of Hungarian winter wheat varieties at various atmospheric $\mathrm{CO}_{2}$ concentrations, temperatures and light conditions, was incorporated into the model. Both the original AFRCWHEAT2 model and the modified AF2MOD model were tested on long-term yield and climatic data series from Györ-Moson-Sopron County.

It was observed that the average yield over the period 1980-1990 was well simulated by both models, but the AF2MOD simulated the annual fluctuations much better: the determination coefficients describing the correlation between the actual wheat yield in Györ-Moson-Sopron county over the whole period and the values generated using the models were $r^{2}=0.32$ for the AFRCWHEAT2 model and $r^{2}=0.86$ for AF2MOD.

A comparison of the results simulated using the AFRCWHEAT2 and AF2MOD models demonstrated that detailed physiological submodels are required for the mathematical description of plant growth if yields are to be accurately estimated and the effects of environmental changes adequately described. A good example of this is the description of the effect of atmospheric $\mathrm{CO}_{2}$ concentration on simulated yield figures, which depended on the climate of the given year in the AF2MOD model, but was described by a simple linear function in the AFRCWHEAT2 model.
\end{abstract}

Keywords: winter wheat, modelling, calibration, elevated $\mathrm{CO}_{2}$ concentration

\section{Introduction}

Plant growth models with various degrees of complexity have been elaborated for the use of plant growers and breeders, ranging from simple statistical regression models to models with a complicated mechanism, capable of simulating anything from a simple process to the behaviour of the whole plant. In addition to experimental research, many scientists also use simulation models to gain a better understanding and description of environmental stress effects, such as high temperature, drought stress, and their effects on the development and yield of plants grown at elevated atmospheric $\mathrm{CO}_{2}$ concentration.

In recent decades more than 70 wheat models have been published internationally, including AFRCWHEAT2, Ceres-Wheat and SIRIUS [9]. These models require detailed weather data, soil characteristics and agronomic descriptions (variety, sowing date, mineral fertilization, irrigation, etc.), which are often not available.

Before the models can be applied, they must be adapted to and calibrated for the given environment and plant variety.

The aim of the present work was to determine the applicability of the AFRCWHEAT2 wheat growth model under Hungarian conditions. The Farquhar 
model, which, when properly calibrated, gives a satisfactory description of the net photosynthesis of Hungarian winter wheat varieties at various atmospheric $\mathrm{CO}_{2}$ concentrations, temperatures and light conditions, was incorporated into the model. Both the original AFRCWHEAT2 model and the modified AF2MOD model were tested on long-term yield and climatic data series from Györ-Moson-Sopron County.

Abbreviations: $\mathrm{EC}=$ elevated air $\mathrm{CO}_{2}$ concentration; $\mathrm{M}=$ average deviation; $r^{2}=$ determination coefficient.

\section{Materials and methods}

\section{Models}

AFRCWHEAT2 is a complex model of wheat growth and development, describing the phenological development, dry matter production and dry matter distribution between the organs for various environmental parameters on a daily time scale $[12,13$, 17]. The model includes a description of plant transpiration and soil evaporation, water and nitrogen movement in the soil, and their uptake by the plant in the course of growth.

Description of net photosynthesis: The photosynthetically active radiation (PAR) reaching the plant stand is calculated from the daily incoming short-wave radiation. This and the leaf area index (LAI) are used to calculate the incoming PAR at each leaf canopy level, using the method reported by Charles-Edwards (1978). The extent of photosynthesis, $P_{s}\left[\mathrm{mg}\left(\mathrm{CO}_{2}\right) \mathrm{m}^{-2} \mathrm{~s}^{-1}\right]$ is described using a quadratic equation fitted to the photosynthesis-light response curve [11], after subtracting the photorespiration [17].

Direct effect of elevated atmospheric $\mathrm{CO}_{2}$ concentration (EC): EC causes a linear increase in the maximum net $\mathrm{CO}_{2}$ assimilation [17] and the rate of electron transport.

In the course of the present work, the photosynthesis section of the AFRCWHEAT2 model was replaced by the Farquhar model [2, 3, 5, 14], thus creating the AF2MOD model. This alteration was possible because the AFRCWHEAT2 model is written in Fortran, and the full code is freely available for scientific purposes.

In order to incorporate the Farquhar model, new parameters had to be defined in the AFRCWHEAT2 model, and these were edited into the initialization data file. This required changes in the parameter-loading program (init.for), the parameter file and the program section describing photosynthesis (phosyn.for).

\section{Data}

Wheat yield and weather data from Györ-Moson-Sopron County were used for the analysis. In order to test the reliability of the models, climatic and mean yield data for the 1961-1990 period were employed. As there was a significant improvement in the cultivation techniques and average yield during this period, these effects were eliminated with the help of a logistic function, so that the yield figures applied would only reflect variations in the weather $[8,6]$. The logistic function was as follows:

$$
y(t)=c_{1}+\frac{c_{2}-c_{1}}{1+e^{\alpha\left(c_{3}-t\right)}}
$$

where $c_{1}$ and $c_{2}$ were the lower and higher saturation values, $c_{3}$ the point of inflection, indicating the year when the growth rate was most rapid, $\alpha$ the parameter 
representing the growth rate and $t$ the time in years. The magnitude of the deviation from the mean was corrected using a linear function taking into account the greater deviation of higher values.

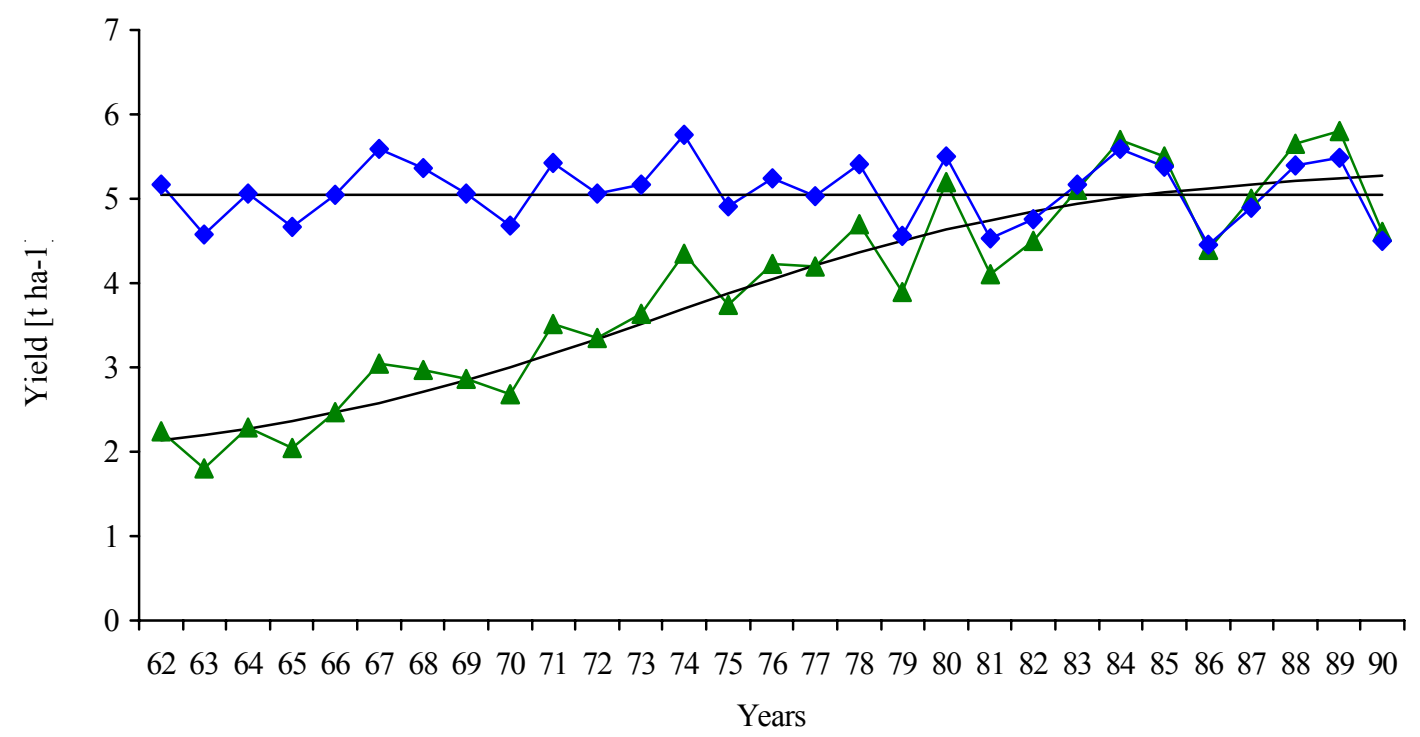

Figure 1. Average wheat yields recorded in Györ-Moson-Sopron County in 1962-1990 (४), the $y(t)$ logistic function, the average yield over the last 10 years (horizontal line) and the yield quantity used in the models (

Daily weather data are available for the period examined. These include daily maximum $\left(T_{\max }\right)$ and minimum $\left(T_{\min }\right)$ temperatures, rainfall sums $(P)$, the number of sunshine hours $(n)$ and the relative humidity $(R H)$. As the selected simulation models also require other climatic data, these were calculated using the relevant equations. These data were the wet $\left(T_{w e t}\right)$ and dry $\left(T_{d r y}\right)$ temperatures and the global radiation $\left(R_{g}\right)$.

$$
T d r y=T_{\min }+\left(T_{\max }-T_{\min }\right) \cdot \sin \frac{\Pi \cdot(h-12+N / 2)}{N+3}
$$

where $N$ is the number of astronomically possible sunshine hours, and $h$ the hour of the day for which the $T_{d r y}$ values were calculated.

$$
\begin{gathered}
T_{w e t}=T_{d r y}+Y, \text { where } \\
Y=\left[-0.05833+\left(-0.00333 \cdot T_{d r y}\right)\right] \cdot R H+\left[5.833+\left(0.333 \cdot T_{d r y}\right)\right]
\end{gathered}
$$

(4; Kempenaar 1997, personal communication).

$$
R_{g}=R_{\max } \cdot\left(a+b \cdot \frac{n}{N}\right)
$$

where $N$ is the number of astronomically possible sunshine hours, $n$ the number of actual sunshine hours, $R_{\max }$ the maximum possible global radiation on the given area, and $a$ and $b$ empirically determined constants which, based on the data of Takács 
(1967), had values of $a=0.41$ and $b=0.46$ in the summer half-year and $a=0.35$ and $b$ $=0.694$ in the winter half-year in Hungary [16]. It should be noted here that during the given period the number of sunshine hours was often recorded subjectively, so in many cases the accuracy of these data leaves much to be desired.

In both models parameter values given by Porter (1993) were used, and in the AF2MOD model the parameterization of the Farquhar photosynthesis model was based on experiments. Mineral fertilizer supplies were set at $90 \%$, so nitrogen limitation was also taken into account in the calculations. In the course of modelling the damage caused by pests, diseases and weeds was ignored. The mean plant density per square metre was taken as 300 and the sowing date as October 10th. For the choice of variety, the data of the wheat variety Martonvásári 8, which is widely grown in Hungary, were used [10].

\section{Results}

It was observed that the average yield over the whole experimental period was well simulated by the models (Table 1), but not the annual fluctuations: the determination coefficients describing the correlation between the actual wheat yield in Györ-MosonSopron county over the whole period and the values generated using the models were $r^{2}$ $=0.28$ for the AFRCWHEAT2 model and $r^{2}=0.37$ for AF2MOD (Fig. 2).

Table 1. Measured and simulated regional yields in Györ-Moson-Sopron County over the average of 28 years (1962-1990) and their deviations

\begin{tabular}{|lccc|}
\hline & Measured & AFRCWHEAT2 & AF2MOD \\
\hline & & & \\
Yield average $\left[\mathrm{t} \mathrm{ha}^{-1}\right]$ & 5.08 & 4.97 & 4.99 \\
Deviation & 0.43 & 0.43 & 0.34 \\
\hline
\end{tabular}

The AF2MOD model gave an extremely good approximation to the yields of the last 10 years $\left(r^{2}=0.86\right)$, while the mean deviation between data pairs was also acceptably low $\left(\mathrm{M}_{\mathrm{AF} 2 \mathrm{MOD}}=0.16\right)$. This can be attributed to the fact that due to the advanced technologies and intensive varieties introduced in the 1980s the yield potential was so stable that the yield depended only on the weather conditions. When testing the AF2MOD model it was found that over the first 20 years of the tested period the variability in the wheat yield was influenced not only by the weather, but also by annual changes in the technology and varieties. This means that the elimination of cultivation techniques and variety effects with the help of a mathematical function is not necessarily the best method to use for model testing. Instead it is advisable to select a period like the 1980s in the present case, when the applied technology and choice of variety remained constant from year to year.

Testing indicated that the AF2MOD model gave a better simulation of historical yield data than the original AFRCWHEAT2 model, so it could be assumed that the AF2MOD model would also provide a more reliable simulation of the probable effects of climate change. 
The purpose of model testing was to analyze the effect of climate change, one of the main causes of which is elevated $\mathrm{CO}_{2}$ concentration (EC). For this reason, it was important to determine the efficiency with which the AFRCWHEAT2 and AF2MOD models simulated the effect of EC. Both models were thus run on the original climatic data for Györ-Moson-Sopron County applying $\mathrm{CO}_{2}$ concentrations of 350 and $515 \mu \mathrm{mol}$ $\mathrm{mol}^{-1}$. The differences between the results, presented in Fig. 3, were investigated for both models. It is clear from the Fig. 3 that the yield-increasing effect of EC did not depend on the climatic data in the case of AFRCWHEAT2, while for AF2MOD a lower yield increase was predicted as the result of EC and the yield increase was a function of the climatic conditions in the given year.
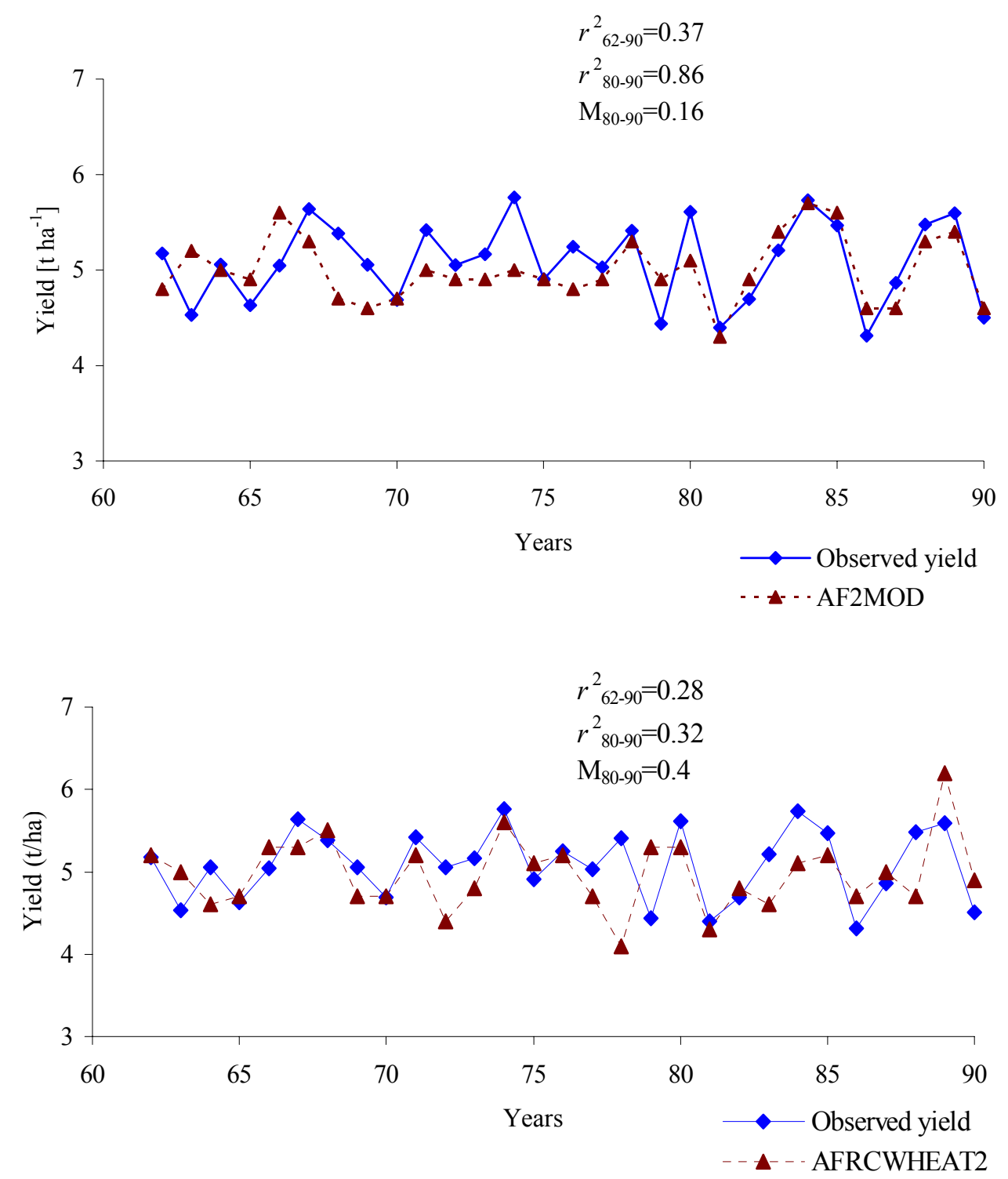

Figure 2. Measured yields and the regional yield quantities simulated each year for GyörMoson-Sopron County using the AFRCWHEAT2 and AF2MOD models in the period 1961-1990. 


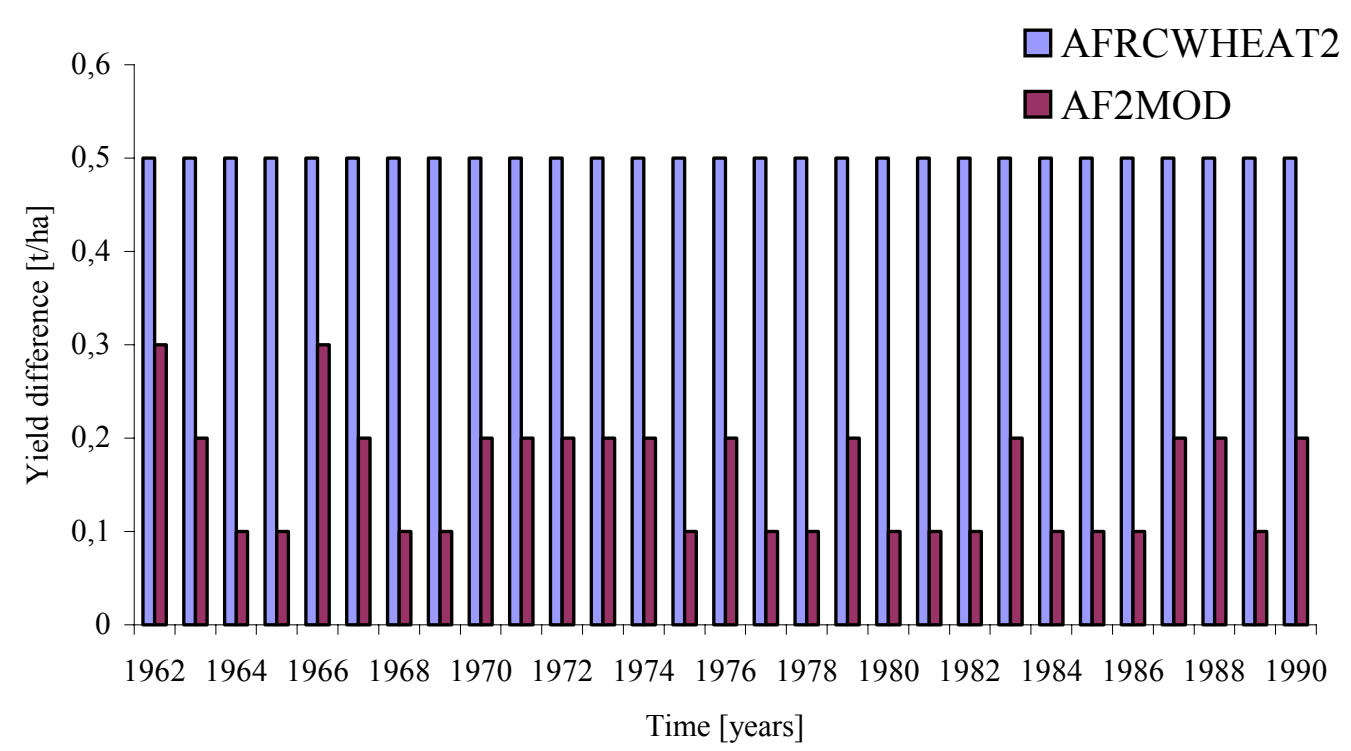

Figure 3. Wheat yield simulation achieved for Györ-Moson-Sopron County using the AFRCWHEAT2 and AF2MOD models with weather data series for 1962-1990 at two $\mathrm{CO}_{2}$ concentrations. The simulations were run at concentrations of $350 \mu \mathrm{mol} \mathrm{mol}{ }^{-1}$ and $515 \mu \mathrm{mol} \mathrm{mol} \mathrm{CO}_{2}$. The figure illustrates differences in the yields.

\section{Discussion}

Earlier results suggested that the Farquhar model was suitable for the description of the net photosynthesis of winter wheat under various environmental conditions (radiation, temperature, atmospheric $\mathrm{CO}_{2}$ concentration) and could thus be usefully incorporated into wheat growth simulation models [7]. In the course of the present work the Farquhar model was thus incorporated into the module of the AFRCWHEAT2 model that describes net $\mathrm{CO}_{2}$ assimilation, thus developing the AF2MOD model.

A comparison of the results simulated using the AFRCWHEAT2 and AF2MOD models demonstrated that detailed physiological submodels are required for the mathematical description of plant growth if yields are to be accurately estimated and the effects of environmental changes adequately described. A good example of this is the description of the effect of atmospheric $\mathrm{CO}_{2}$ concentration on simulated yield figures, which depended on the climate of the given year in the AF2MOD model, but was described by a simple linear function in the AFRCWHEAT2 model.

In the course of validation it was observed that the yield averages recorded in the first half of the tested period were well simulated by the models, by not the annual figures. By contrast, the yield obtained in Györ-Moson-Sopron County over the last 10 15 years was far better approximated by the AF2MOD model than that of earlier years. This could be explained by the fact that in the 1980s, when advanced technologies and intensive varieties were introduced, the yield potential became so stable that where the yield depended almost entirely on the climatic conditions. It is thus recommended that models should be tested on periods when the technology applied and the varieties chosen remained constant from year to year, such as the 1980s in the present case [6]. 


\section{REFERENCES}

[1] Charles-Edwards, D.A. (1978): An analysis of the photosynthesis and productivity of vegetable crops in the United Kingdom. - Annals of Botany 42: 717-731.

[2] Farquhar, G.D., von Caemmerer, S. (1982): Modelling of photosynthetic response to environmental conditions. - In: Lange, O.L., Nobel, P.S., Osmond, C.B., Ziegler, H., (Szerk.): Physiological plant ecology II. Water relations and carbon assimilation. Encyclopedia of plant physiology, New series, Berlin: Springer-Verlag, Vol. 12B. 549587. p.

[3] Farquhar, G.D., von Caemmerer, S., Berry J.A. (1980): A biochemical model of photosynthetic $\mathrm{CO}_{2}$ assimilation in leaves of $\mathrm{C}_{3}$ species. - Planta 149: 78-90.

[4] Goudriaan, J., van Laar, H.H. (1994): Modelling Potential Crop Growth Processes. Textbook with Exercises. - Kluwer Academic Publishers. 238 p.

[5] Harley, P.C., Sharkey, T.D. (1991): An improved model of $\mathrm{C}_{3}$ photosynthesis at high $\mathrm{CO}_{2}$ : Reversed $\mathrm{O}_{2}$ sensitivity explained by lack of glycerate re-entry into the chloroplast. - Photosynthesis Research 27: 169-178.

[6] Harnos, N. (2003): A klímaváltozás hatásának szimulációs vizsgálata őszi búza produkciójára. „AGRO-21” Füzetek, 2003. 31: 56-73.

[7] Harnos, N., Tuba, Z., Szente, K. (2002): Modelling net photosynthetic rate of winter wheat in elevated air $\mathrm{CO}_{2}$ concentrations. - Photosynthetica 40(2): 293-300.

[8] Harnos, Zs. (1996): Modelling crop response in Hungary. - In: Harrison, P.A., Butterfield, R.E., Cowning, T.E. (ed.): Climate Change, Climatic Variability and Agriculture in Europe. Annual Report. Environmental Change Unit, University of Oxford. 179-189. p.

[9] Jamieson, P.D., Porter, J.R., Goudriaan, J., Ritchie, J.T., van Keulen, H., Stol W. (1998): A comparison of the models AFRCWHEAT2, CERES-Wheat, Sirius, SUCROS2 and SWHEAT with measurements from wheat grown under drought. - Field Crops Research 55: 23-44.

[10] Kovács, G.J., Németh, T., Ritchie, J.T. (1995): Testing Simulation Models for Assessment of Crop Production and Nitrate Leaching in Hungary. - Agricultural Systems 49(4): 385-397.

[11] Marshall, B., Biscoe, P.V. (1980): A model for $\mathrm{C}_{3}$ leaves describing the dependence of net photosynthesis on irradiance. I. Derivation. - Journal of Experimental Botany 31: 2939.

[12] Porter, J.R. (1984): A model of canopy development in winter wheat. - Journal of Agricultural Science 102: 383-392.

[13] Porter, J.R. (1993): AFRCWHEAT2 A model of the growth and development of wheat incorporating responses to water and nitrogen. - European Journal of Agronomy 2: 69-82.

[14] Sharkey, T.D. (1985): Photosynthesis in intact leaves of $C_{3}$ plants: Physics, physiology and rate limitations. - The Botanical Review 51: 53-105.

[15] Takács, L. (1967): A globálsugárzás számítása. Az Országos Meteorológiai Intézetben 1967-ben elhangzott referátumköri elöadás. Kézirat.

[16] Varga-Haszonits, Z. (1977): Agrometeorológia. - Mezőgazdasági Kiadó, Budapest.

[17] Weir, A.H., Bragg, P.L., Porter, J.R., Rayner, J.H. (1984): A winter wheat model without water or nutrient limitations. - Journal of Agricultural Sci. 102: 371-383. 